\title{
Intercultural Communicative Competence: Why Is It Significant and How Can It Be Enhanced in EFL Settings?
}

\author{
Seçil TÜMEN-AKYILDIZ1', Vildan ÇELiK², Kwestan Hussein AHMED³
}

\begin{abstract}
In the current literature on foreign language teaching, it has become clear that having the requisite ability of intercultural communicative competence (ICC) to be aware of different cultures, respect them, and interact with people from different cultures is crucial. Language is connected to culture and societies, in which people need to communicate with one another. English as a lingua franca provides a means of communication among different cultures. Thus, English as a foreign language (EFL) teaching classes offer perfect situations to foster ICC. From this viewpoint, this article gives an account to raise awareness of ICC in EFL settings by explaining ICC and its relationship with language, describing the significance of ICC, and illustrating some suggestions in the literature for the enhancement of ICC in EFL classes. This paper seeks to improve EFL teachers' understanding of intercultural communication and to help them with their classroom practices.
\end{abstract}

Keywords: Culture, Language, English as foreign language, Intercultural communicative competence

\section{Kültürlerarası İletişimsel Yeti: Neden Yabancı Dil Öğretiminde Önemlidir ve Nasıl Geliştirilebilir?}

Öz: Güncel yabancı dil öğretimi yazınında farklı kültürlerden haberdar olmak, onlara saygı duymayı öğrenmek ve dünyanın herhangi bir yerinde insanlarla rahat iletişim kurabilmek için kültürlerarası iletişim yetisine sahip olmanın zorunlu olduğu görülmektedir. Dil kültürle ve insanların birbirleriyle iletişim kurması gereken toplumlarla bağlantılıdır. Evrensel dil olarak İngilizce ise farklı kültürlerin iletişimini sağlayan bir araçtır. Bu nedenle yabancı dil olarak İngilizce öğretim sınıfları kültürlerarası iletişimsel yetiyi desteklemek için elverişli yerlerdir. Bu noktadan hareketle bu makale kültürlerarası iletişimsel yetinin önemini vurgulayıp dil ile arasındaki ilişkiyi açıklayarak alan yazında yabancı dil sınıflarında bahsi geçen becerinin geliştirilmesi için ortaya konan çalışmalardan örnekler vermeyi amaçlamaktadır. Bu şekilde yabancı dil öğretmenlerinin kültürlerarası iletişimin önemini kavramalarına ve sınıflarında bu yetiyi geliştirmek için uygulamalar yapmalarına katkı sağlamak hedeflenmektedir.

Anahtar Sözcükler: Kültür, Dil, Yabancı dil olarak İngilizce, Kültürlerarası iletişimsel yeti

${ }^{1}$ Firat University, Faculty of Humanities and Social Sciences, Western Languages and Literatures, Elazığ, Turkey, e-mail: stakyildiz@firat.edu.tr ORCID: https://orcid.org/0000-0003-4116-7344

${ }^{2}$ Ministry of National Education, Elazığ, Turkey, e-mail: ucmazvildan@gmail.com, ORCID: https://orcid.org/0000-0001-5418-7243

${ }^{3}$ Firat University, faculty of Humanities and Social Sciences, Western Languages and Literatures, Elazı ğ, Turkey, e-mail: kwestanenglish@gmail.com ORCID: https://orcid.org/0000-0002-8403-8529 
People must be well aware of different cultures and gain intercultural communicative competence (ICC) to be successful in interacting with others (Barker, 2016) as a consequence of the globalized world and novel technologies for communication, both of which have led to the erasure of national borders and created a universal link (Mostafaei Alaei and Nosrati, 2018). ICC also plays a vital role in improved communication among students (Chen and Starosta, 1996). It is defined as the ability to obtain general knowledge, attitudes, and skills related to both the culture-specific and general types of necessary knowledge for successful communication and interaction with people from other cultures. It is also a variable, progressive, and continuing issue that mentally, cognitively, and actively affects students (Dunne, 2011; McKinnon, 2012; Paige, Jorstad, Siaya, Klein and Colby, 2000). Therefore, integration of ICC within the education system is required, and teachers should encourage their learners to enhance it (López-Rocha, 2016).

Hoa (2011) indicated that language means communication. The globalized world has socially and economically required individuals to utilize a common way of communication, which is the English language (Alptekin, 2002). However, knowledge of the culture is necessary for language as a means of communication (Hoa, 2011). Language is connected to culture, societies, and communities in which people must communicate with one another. For this reason, in English as a foreign language (EFL) classes, students should be motivated to become fluent multicultural speakers (Garrido and Álvarez, 2006) to avoid incongruous circumstances, severe confusion, or unclear communication, all of which can occur if proper cultural knowledge does not exist during communication (Chlopek, 2008).

Many scholars have highlighted the significance of teaching culture in foreign language classes (Kazykhankyzy, 2019). Moreover, several countries have put ICC into practice in their language teaching policies, such as the United States and the United Kingdom (Mostafaei Alaei and Nosrati, 2018). Despite its significance, it is not given adequate attention by language teachers, who generally maintain a mindset of "teaching language first, and introducing culture later" (Omaggio, 1993, cited in Hoa, 2011, p. 86). In this sense, the main goal of this study is to raise awareness regarding ICC in EFL settings by explaining ICC and its relationship with language, describing the significance of ICC, and illustrating some suggestions in the literature for the enhancement of ICC in EFL classes. This study aims to provide new insight for EFL teachers in terms of understanding ICC and to help them in terms of practice.

\section{Culture, ICC, and Its Relationship with Language}

Matsumoto (1996 cited in Spencer-Oatey, 2012, p. 2) defined culture as “...the set of attitudes, values, beliefs, and behaviors shared by a group of people, but different individual, communicated from one generation to the next". For Hofstede (1994 cited in Spencer-Oatey, 2012, p. 2), culture is "the collective programming of the mind which distinguishes the members of one group or category of people from another". ICC, on the other hand, is "the knowledge, motivation, and skills to interact effectively and appropriately with members of different cultures" (Wiseman, 2002, cited in Mirzaei and Forouzandeh, 2013, p. 303). Chen and Starosta (1998, p. 28) explained ICC as "the ability to effectively and appropriately execute communication behaviors that negotiate each other's cultural identity or identities in a culturally diverse environment". According to Deardoff (2006 cited in Mirzaei and Forouzandeh 2013, p. 304), ICC is "the ability to communicate effectively and appropriately in intercultural situations based on one's intercultural knowledge, skills and attitudes", while Jokikokko (2005) described it as an ethical approach that effectively reveals such fundamentally acceptable lifestyles of thinking and behaving.

For Chen and Starosta (1996), ICC is made up of three different aspects that are linked to each other. Intercultural sensitivity is recognized as the affective component and refers to being ready to recognize and respect cultural nuances in intercultural communication. Intercultural awareness is the cognitive element and refers to comprehending cultural norms or values that influence how people think and act. As a behavioral feature of intercultural communication competence, intercultural adroitness emphasizes the skills required to behave efficiently in cross-cultural contexts (Chen and Starosta, 1998).

Deardorff $(2004,2006)$ suggested three components of ICC that represent a transformation across attitudes, skills, and knowledge, understanding a person's level, and the internal and external effects at the 
level of interaction. It is appropriate to shift immediately through attitudes and skills/knowledge to external outcomes. Furthermore, this shifting is a continuous process that explains the development of ICC. According to Fantini (2000) and Fantini and Tirmizi (2006), with the key components of knowledge, attitudes, skills, and awareness, intercultural communication competence is a dynamic capacity. It is claimed that awareness is the key element of intercultural communication competence and contains variations from others' and one's own culture, which can be enhanced by reflective thinking and self-examination. Through the acquisition of knowledge, attitudes, and skills, awareness can be improved. Fantini created a graphical model in which the central component of awareness is surrounded by behaviors, abilities, and information (Fantini, 2000; Fantini and Tirmizi, 2006). The aforementioned graphical model is similar to Byram's (1997) model, which will be discussed later in this paper. His model is noteworthy in terms of foreign language teaching.

Kramsch and Widdowson (1998) stated that people carry out their social lives primarily through the medium of a language that is inextricably linked to culture in many respects, as used in communication contexts. Cultural reality is conveyed, embodied, and signified by language. Thus, culture and communication can be regarded as counterparts because culture determines who communicates with whom as well as how to communicate with others. It allows people to decide how individuals transmit messages and the expectations they have in regard to texts as well as the situations and conditions. Thus, the basis of communication is culture (Thanasoulas, 2001).

In this sense, culture cannot be neglected in language classes. Accordingly, as reported by Thanasoulas (2001), several educators have been interested in the role of culture in foreign language learning since the 1960s. Canale and Swain (1980), in particular, highlighted a communicative approach for combining language and culture more naturally. Students' understanding of the target culture is carried out from the viewpoint of their cultural background and knowledge. Culture education is not simply studying the target culture; it is also knowing how the culture of the target language communicates with an individual's personal context (Liaw, 2006).

For students' language improvement and intercultural competence, "the five C's" (communication, cultures, connections, comparisons, communities) were introduced as the standards for foreign language learning (see Figure 1). According to these standards, students who want to be good at speaking the target language should communicate for actual purposes, recognize multicultural and international matters, connect with other fields and learn new things, draw comparisons with their own culture and language, and interact in different communities (Lear and Abbott, 2008).

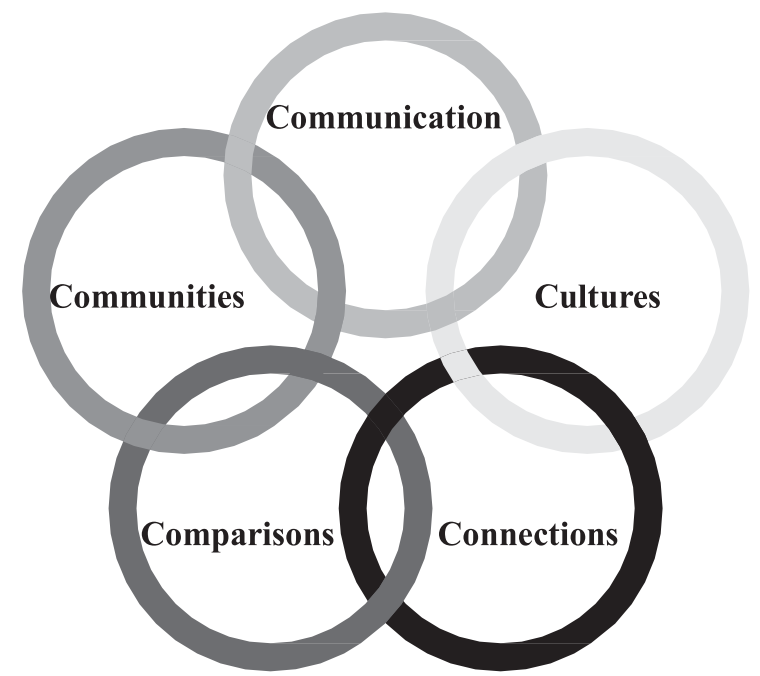

Figure 1. The five C's of foreign language teaching (Lear and Abbott, 2008, p. 77)

Hence, one of the objectives of English language teaching is to teach students to be intercultural citizens and enable them to communicate without separating the target language from its culture. Although ICC has been considered an essential competency in this era, the implementation of intercultural contexts in English 
language education has been neglected in education systems (Tran and Seepho, 2016); thus, it should be adequately addressed.

\section{ICC in EFL Settings}

Teaching or learning a foreign language is not just facing linguistic issues. Rather, cultural elements should be covered as well (Atay, Kurt, Çamlıbel, Ersin and Kaslığlu, 2009) because learning a foreign language connotes learning a novel culture that cannot be conceived without language (Chaouche, 2016). Vo (2017) stated that both intercultural communication and the English language construct a bridge for communication among different cultures because English is a lingua franca. Through English as the target language, EFL students are able to interact with people around the world in various fields such as technology, business, tourism, and science, which allows them to be involved in international as well as intercultural communication (Chlopek, 2008).

Although the main focus of intercultural approach-based teaching is the targeted cultures, it often concerns the similarities between learners' native culture and the target culture. Hence, it enables students to cultivate a sensitive attitude toward their own culture and society (Kramsch, McConnell-Ginet and GinetMcConnell, 1992). Having knowledge of a specific country's customs, practices, values, and culture also enables students to understand the literature of that society and to use their English correctly (Lázár, 2005). Moreover, a lack of cultural competence can cause problems for students in intercultural situations, such as disunity, miscommunication, and even relationship conflicts (Ho, 2009). Generally, EFL students are acquainted with various cultures around the world, but to evaluate those cultures critically, they need to have the capacity to compare and contrast different cultures (Irimia, 2012). According to Chaouche (2016), EFL teaching involving an intercultural approach has two objectives:

1. Helping learners acquire the communicative competence needed to communicate in speaking or writing to formulate what they want to say/write correctly and appropriately.

2. Developing learners' intercultural competence, that is, their ability to ensure a shared understanding by people of different social identities, and their ability to interact with people as complex human beings with multiple identities as well as their own individuality (p. 36).

In the aforementioned respects, ICC has attracted considerable attention from researchers and teachers in EFL settings. Several researchers from various parts of the world have focused on the role of ICC in language classes. Lessard-Clouston (1996) conducted a study with 16 Chinese educators regarding culture in EFL teaching and learning. EFL teachers indicated that they needed a better understanding to focus on culture. The results showed that educators maintained the significance of culture in EFL education. Sercu (2002) examined whether German, French, English, and Flemish instructors promote intercultural priorities and facilitate the development of intercultural communication in foreign language classes. The data showed that foreign language educators support the goal of developing intercultural competence and wish to improve intercultural communication abilities in their students. Vo (2017) conducted survey research with Vietnamese lecturers on the importance of ICC in EFL. It was reported that the participant lecturers were well aware of the necessity of ICC in teaching English, and they were ready to engage in ICC in their teaching practice. However, they asserted some inhibiting factors, such as limited knowledge regarding ICC, limited time and resources to integrate ICC, the influence of social and religious issues, and limited environments for intercultural communication. The researcher suggested that conditions should be constructed that favor ICC, and training workshops for teachers should be held to engage ICC in EFL. Similarly, Zhang (2017) revealed the incompetent ICC levels of English language teachers due to a lack of sufficient intercultural experience and recommended that they to improve their ICC levels to enhance their teaching practices.

Furthermore, Castro et al. (2004) examined whether Spanish English-language teachers encourage students to learn intercultural skills. The collected data showed that they were more likely to achieve cultural learning targets in foreign language teaching classrooms. Atay (2005) reported that prospective English language teachers were aware of the importance of intercultural competence; nevertheless, they did not find 
themselves sufficiently knowledgeable in terms of the target culture. In a study conducted by Atay et al. (2009), it was demonstrated that Turkish EFL teachers prioritized teaching the language with the goal of communicating rather than enabling students to learn the target culture. Although the participants reported having favorable attitudes toward integrating cultural issues into their teaching, their practices demonstrated the opposite.

\section{Suggestions for EFL Teachers to Enhance Students' ICC}

As claimed by Er (2006), language is an instrument that expresses a society's way of thinking. As a result, educators have been trying to develop models, approaches, and methods for teaching English to facilitate ICC among students in terms of varied tasks and activities. Thereby, students can understand the culture of the language and build awareness, at which point they will make real progress in ICC (Gökmen, 2005).

Byram (1997) emphasized the value of language and language skills in the ICC model with five components, including knowledge, skills, and attitudes, as presented in Figure 2. In his model, it is recognized that teachers are required to instruct students through the acquisition procedure about attitudes, knowledge, and skills related to intercultural competence as they use a foreign language. Accordingly, they should guide learners through practice to interpret the beliefs of others, not merely their own (Byram, 1997; Moeller and Nugent, 2014). Thus, English language teachers play the most prominent role in promoting intercultural communication in education by emphasizing its significance in language teaching (Zhang, 2017); therefore, they should also understand the components of the model.

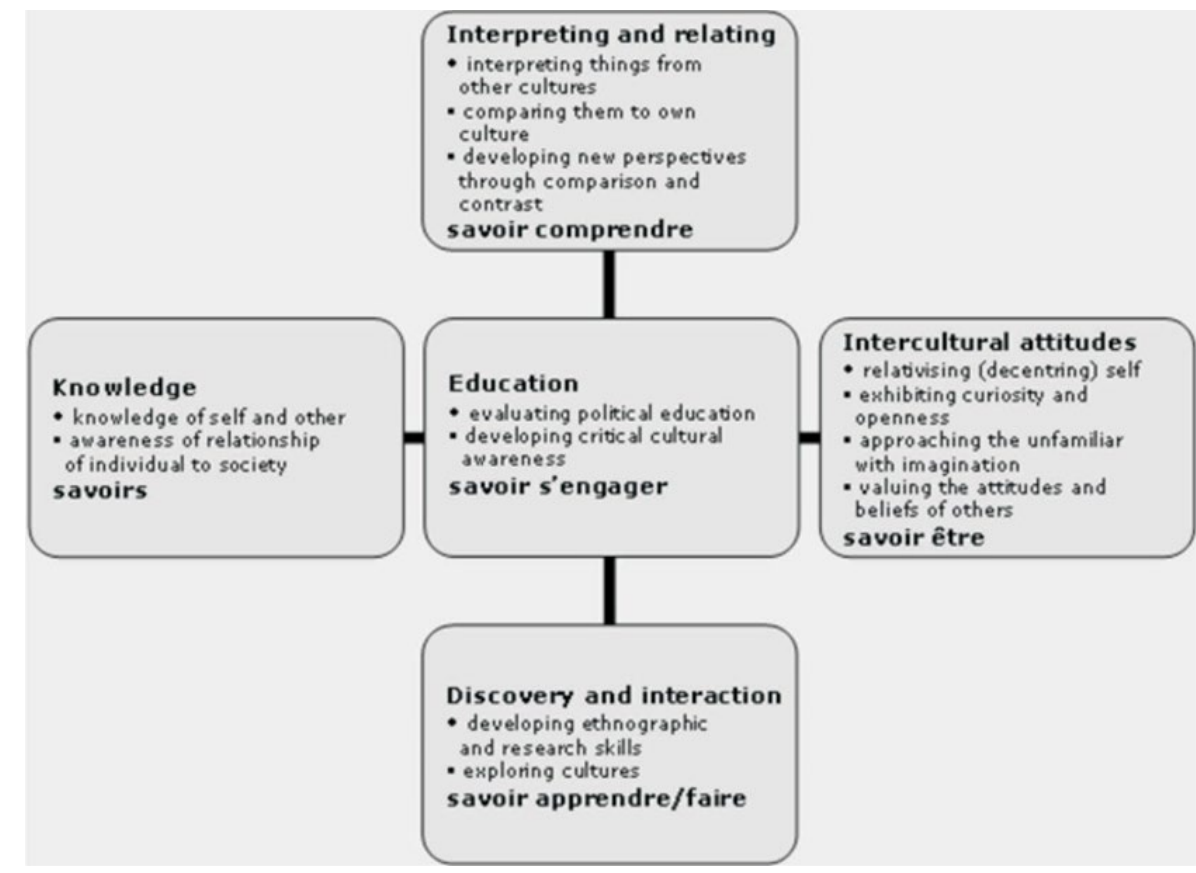

Figure 2. Byram's model of ICC (taken from Vo, 2017, p. 22)

Knowledge (saviors) describes the knowledge of other social groups and their characteristics, practices, and products. As a crucial factor, knowledge is not only specific knowledge of a particular culture; it also involves knowing how communities and identities work and what is required in intercultural interaction. The role of instructors is to build skills and attitudes as well as expertise, and they may collect information about other countries together with their students. Accordingly, they do not need to be the only one with or the main focus of such knowledge (Byram et al., 2002; Chaouche, 2016; Moeller, and Nugent, 2014).

Attitudes (savoir être) regard openness and curiosity related to learning about other cultures as well as appreciating others' attitudes and beliefs. This factor can be defined as enthusiasm and transparency, a willingness to maintain skepticism of other cultures, and confidence in one's own society. It is a tendency to universalize the principles and beliefs in one's culture and not to believe that they are the only acceptable ones 
or that they are inherently right. It is the capacity to see how they could appear from the viewpoint of a different background, culture, beliefs, and attitudes. Foreign language knowledge is among the developmental needs of individuals, but it is crucial to provide culturally relevant skills, such as being polite toward all different cultures (Byram, 1997).

Skills of interpreting and relating (savoir comprendre) are related to the ability to interpret, identify different cultural elements, and develop new perspectives by comparing and contrasting different cultures. This factor can be explained as the capacity to interpret, clarify, and connect information or experience from another culture to one's target culture (Byram, 2008; Byram, Gribkova and Starkey, 2002). Atay et al. (2009) defined this skill as the capacity to describe and clarify multiple cultural contexts and to mediate between the two as well as to work toward new cultural perspectives.

Skills of discovery and interaction (savoir apprendrelfaire) describe the skill of searching for and discovering new information about cultures and communicating by taking account of the knowledge discovered. This skill is the ability to acquire new information regarding various cultures and cultural practices to communicate and to engage with knowledge, behaviors, and experiences during communication. Therefore, individuals must advance their ability to find new knowledge and integrate it with their own culture. Intercultural speakers must discover new knowledge and interact with others effectively (Byram et al., 2002; Chaouche, 2016).

Critical cultural awareness (savoir s'engager) refers to the aptitude to evaluate the behaviors, practices, and properties of one's own culture and different cultures. The concept of critical cultural awareness lies in the center of the aforementioned skills and factors, which is very important for the educational goals of intercultural competence instruction in EFL (Byram, 2008). It is a skill to determine, in a critical way, the context of clear standards, viewpoints, and behaviors within an individual's culture and others' cultures (Atay et al., 2009; Byram et al., 2002; Moeller and Nugent, 2014).

In her article, Vo (2017) summarized Hartmann and Ditfurth's (2007) ICC activities developed for EFL classes. These activities were built upon the Byram's (1997) ICC model and its components, as previously explained. For the attitude component, virtual and face-to-face projects such as email exchange or authentic texts such as songs and interviews were suggested, while for the knowledge component, inviting guest speakers and working with stereotypes in the classroom were suggested. Tasks on literary texts, such as writing new scenes and endings, and simulations to encourage students to think about a given circumstance from different cultural viewpoints were recommended to enhance the skills of the interpreting and relating component. Regarding the skills of the discovering and interacting component, drawing comparisons among emails, ethnographic observation tasks, discussions on cultural misunderstandings, and virtual and face-toface projects, as for the attitude component, were given as activity examples. Finally, in terms of the critical cultural awareness component, comparing what two different societies do to manage immigration can be regarded as an example.

According to Hoa (2011), EFL teachers should include three domains in their teaching to make ICC more effective: cognitive, affective, and behavioral. The first step, cognition, concerns knowledge and cognitive awareness regarding a culture. The specific knowledge of culture, including historical, political, and geographical facts as well as common rules of that culture, is taught at this level. The affective level of the students should also be considered because in intercultural communication, anyone may feel stressed, anxious, confused, or angry as a result of cultural differences. Thus, students should be trained to recognize and control their emotions when interacting with people from various cultural backgrounds. Finally, the behavioral dimension should be taken into consideration for successful intercultural communication, as it helps students identify and learn other people's behavioral changes while communicating.

In Hoa's (2011, p.93) article, several learning activities to improve ICC in EFL classes are summarized and suggested. The first can be regarded as a traditional approach-giving lectures and providing reading materials on the relevant different cultures-yet it will help students be prepared for intercultural communication in terms of cognitive level. The second, cultural assimilators, which are described as "a brief description of critical incidents of cross-cultural behaviors that would probably be misunderstood by 
students" are offered. These assimilators help students distinguish cultural values, which foster students' understanding of complicated cultural issues and facilitate improvement of their affective and cognitive levels. Third, EFL teachers can use written or recorded cultural capsules in which they are expected to show significant differences between cultures by providing short presentations with visuals of these cultural differences. Students would then be asked a variety of questions and discuss the topics together. Fourth, minidramas with short episodes involving miscommunication examples are suggested for self-confrontation. Fifth, role-playing, in which students pretend to be part of intercultural communication, is also good for students. The other activity example is group or pair discussions on several intercultural topics. Finally, if possible, it is suggested to invite foreigners to the classroom to discuss their cultures, giving students an opportunity to listen to their experiences personally.

In her article, Chlopek (2008) made remarkable contributions to the intercultural approach in EFL classes with detailed activity examples and suggestions to prevent possible problems that may occur during the implementation of the intercultural approach. Regarding the latter, she first suggests 'motivating students.' At the beginning, the students will likely not find learning about different cultures interesting. Thus, a successful EFL teacher should start his/her instruction by motivating them to become interested in other cultures. Teachers need to explain to students the significance of having intercultural competence to protect them from difficult, incongruous, or awkward conditions that they may encounter. Moreover, intercultural lessons should ensure a friendly environment and attract students' attention. 'Encouraging appropriate attitudes' is Chlopek's second piece of advice. She emphasized that learners must attempt to understand cultures around the world and not see them as a mystery or something strange. Therefore, teachers should inform students about different beliefs, behaviors, and values to help prevent students from developing prejudices that will negatively affect intercultural competence. Here, it is crucial for teachers to note that they should not attempt to 'convert' learners to other cultures; rather, they should aid students in developing an understanding of such cultures as students may not always welcome certain cultural elements. 'Considering students' ages' in intercultural teaching is also suggested for EFL teachers as it is harder to conduct intercultural lessons with younger students, compared to adults who can easily comprehend why they need intercultural competence. However, it is not impossible to work with younger students if lessons are learnercentered, fun, and exciting (Chlopek, 2008) and if the interesting activities recommended here are integrated into the lessons.

The activity examples offered by Chlopek (2008) are given under three different titles: stage one, stage two, and stage three. Each stage includes five activity examples with detailed explanations and additional ideas regarding how to implement them. According to her, with the activities in stage one, students are expected to examine their own culture and develop an objective point of view. For instance, the first activity here involves brainstorming about culture and its dimensions, preparing a mind map about various cultural aspects as a group and presenting those maps to other groups as well as writing down the features of their own culture and inspecting their environment as homework. Among other activities, there are whole-class discussions on students' observations, inventing alternatives to the existing customs by using different cultural manifestations and designing a web page that introduces their culture. In stage two, activities for gaining new perspectives on English-speaking countries' cultures are suggested. For example, pictures that show people's different body language or gestures can be handed out to the groups, and the teacher can ask the students to determine what these people may feel or think. Later, each group can be asked to draw similar pictures depicting facial expressions or body language and to present them. In another activity, interesting and somewhat contradictory authentic texts from newspapers, magazines, and the Internet are given to students. With the help of the teacher, they then analyze those texts in terms of cultural aspects and compare and contrast them with their native culture. With the activities in stage three, students are informed about world cultures beyond those that are English-speaking. One of the engaging activities in this stage is having students watch a part of a film demonstrating cultural aspects and involving a misinterpretation or dispute. After watching, students discuss these misunderstandings or disputes and consider what the film characters should have done to prevent them. The other activities in each stage are beneficial and inspiring, although not 
all are mentioned here. Overall, reading Chlopek's article (2008) and utilizing the activities she presents in EFL classrooms can foster students' intercultural competence.

In their article, Moeller and Nugent (2014) also mentioned five ICC activities for foreign language classes, which can be utilized in EFL classes directly or with little adaptation. Furstenberg's (2010) Cultura, an online blog exchange program in which American and French students participated, is given as the first activity example. In this program, comparison and analyses of different texts, such as surveys, websites, images, films, literature, and videos taken from both cultures, are performed in addition to asking and answering questions regarding American and French cultures. Through these comparisons, analysis, and question-answer sessions in an online forum, students can become more knowledgeable about and tolerant of other cultures and different points of view while becoming more aware of their own cultural beliefs, values, and experiences. Moreover, such online exercises are beneficial for acquiring new vocabulary and grammar rules of the target language, as students read materials and posts in the blog. A similar program can be designed and implemented for EFL students worldwide. As a second example, attitude exploration with the OSEE tool, which was created by Deardoff and Deardoff (2000) for the analysis of students' attitudes toward other people and cultures, is introduced and explained for implementation in language classrooms. As indicated by Moeller and Nugent (2014, p.10), OSEE stands for "O: Observe what is happening, S: State objectively what is happening, E: Explore different explanations for what is happening, E: Evaluate which explanation is the most likely one". The OSEE tool can be utilized by teachers when they initially start teaching intercultural competence. These four steps, detailed explanations of which can be found in the article, are applied, respectively, while students watch a film or a video about a topic involving cultural situations. According to Moeller and Nugent (2014, p.10), this tool "creates space for learners to consider their preconceived ideas about people from other cultures so that negative beliefs are transformed during exercises focusing on objective observation, research, and evaluation". Documenting transformation collectively is the third example and was based on Byram et al.'s (2002) ideas. The activity aims to help students understand how their perceptions differ from the facts and why the intercultural process is significant. In the activity, students are asked to share their ideas about a specific cultural topic, and the teacher writes them down on a paper, which will be regarded as a reference to students' perceptions. Students are then allowed to freely research the topic by analyzing articles, advertisements, surveys, or graphs; they are also encouraged to discover the similarities and differences between their native culture and the target culture they are researching. In the end, they gather around the paper, which is filled with their previous ideas, and discuss the changes in their beliefs and perceptions regarding the topic. A new paper is prepared with the information they all gathered through their research. For teachers who are interested in technology, Moeller and Nugent (2014) also suggest doing this activity online on padlet.com or popplet.com. An additional activity example concerns proverbs, which are one way to explain the attitudes of people from other cultures. This activity contains many steps or methods to follow. These steps involve, in brief, an introduction to proverbs along with some general questions about them: a jigsaw learning task with four groups and four topics about the proverbs to be researched; preparing a poster with the information that each group has learned via jigsaw task and giving a presentation; doing an envelope activity in which students match the proverbs of the two cultures and discuss the values that the cultures share, giving a scenario in which students imagine themselves and have to search for a different proverb on the Internet, sharing what they have found about each proverb, and finally, asking students to write a new proverb in the target language and create a character on voki.com who speaks the target language. As the final ICC activity example, Moeller and Nugent (2014) recommended artifact exploration. This requires the teacher to introduce a context involving special objects that give information regarding the target culture, and students attempt to discover cultural facts about these objects by conducting research and finding the answers to the questions posed by the teacher.

\section{Conclusion}

"Though we may not have fully become a 'global village' there is no denying that the various cultures of the world are far more accessible than ever before, and that the peoples of these cultures are coming into contact at an ever-increasing rate" (Spitzberg, 1997, p. 379). Twenty-four years after Spitzberg's statement, we 
can now declare that in 2021, we indubitably live in a 'global village' where people from different cultural backgrounds can meet and communicate with each other much more easily than they did previously. In such a global village, possessing the requisite ability of ICC is crucial, and language classes, including EFL, are perfect places to foster this skill. Teachers should provide the proper conditions to help students interact effectively with ICC in the classroom. Accordingly, to encourage EFL learners to become sufficiently competent in terms of intercultural information and communication, instructors should first be well-informed regarding ICC and must be able to follow some steps and integrate different activities and tasks designed for the specific purpose of developing ICC in their practices.

\section{Declarations}

Acknowledgements: None.

Authors' Contributions: This review article has been written and revised divided equally by three of the authors.

Ethics Committee Approval: There is no requirement of Ethics Committee Approval for review articles.

Competing Interests: The authors have no conflict of interests.

Funding: The authors received no financial support for this study, authorship, or publication of this article.

\section{References}

Alptekin, C. (2002). Towards intercultural communicative competence in ELT. ELT Journal, 56(1), 57-64.

Atay, D. (2005). Reflections on the cultural dimension of language teaching. Language and Intercultural Communication, $5(3,4)$, 222-237.

Atay, D., Kurt, G., Çamlıbel, Z., Ersin, P., \& Kaslığlu, Ö. (2009). The role of intercultural competence in foreign language teaching. Inonu University Journal of the Faculty of Education, 10 (3), 123-135.

Barker, G. G. (2016). Cross-cultural perspectives on intercultural communication competence. Journal of Intercultural Communication Research, 45(1), 13-30.

Byram, M. (1997). Teaching and assessing intercultural communicative competence. Clevedon, UK: Multilingual Matters.

Byram, M. (2008). Intercultural citizenship and foreign language education. Recuperado el, 20, 122-132.

Byram, M., Gribkova, B., \& Starkey, H. (2002). Developing the intercultural dimension in language teaching: A practical introduction for teachers. Language Policy Division, Directorate of School, Out-of-School and Higher Education, Council of Europe.

Canale, M., \& Swain, M. (1980). Theoretical bases of communicative approaches to second language teaching and testing. Applied linguistics, 1(1), 1-47.

Castro, P., Sercu, L., \& Méndez García, M. d. C. (2004). Integrating language and culture teaching: an investigation of Spanish teachers' perceptions of the objectives of foreign language education. Intercultural Education, 15(1), 91-104.

Chaouche, M. (2016). Incorporating intercultural communicative competence in EFL classes. Paper presented at the Arab World English Journal, December 2016 ASELS Annual Conference Proceedings. 32-42.

Chen, G. M., \& Starosta, W. (1998). A review of the concept of intercultural awareness. Human Communication, vol. 2, 1998-1999, 27-54.

Chen, G. M., \& Starosta, W. J. (1996). Intercultural communication competence: A synthesis. Annals of the International Communication Association, 19(1), 353-383.

Chlopek, Z. (2008). The Intercultural Approach to EFL Teaching and Learning. English Teaching Forum, $46(4), 17-18$. 
Deardorff, D. K. (2004). The identification and assessment of intercultural competence as a student outcome of internationalization at institutions of higher education in the United States. North Carolina State University.

Deardorff, D. K. (2006). Identification and assessment of intercultural competence as a student outcome of internationalization. Journal of studies in international education, 10 (3), 241- 266.

Deardorff, D.K. \& Deardorff, D.L. (2000), OSEE Tool. Presentation at North Carolina State University, Raleigh, N.C.

Dunne, C. (2011). Developing an intercultural curriculum within the context of the internationalisation of higher education: Terminology, typologies and power. Higher Education Research E Development, 30 (5), 609-622.

Er, O. K. (2006). The effects of culture in foreign language curriculum. Ankara University Journal of Faculty of Educational Sciences, 39(1), 1-14.

Fantini, A. \& Tirmizi, A. (2006). Exploring and Assessing Intercultural Competence. World Learning Publications, 1, 1-74.

Fantini, A. E. (2000). A central concern: Developing intercultural competence. SIT occasional papers series, 1, $25-42$.

Furstenberg, G. (2010). A dynamic, web-based methodology for developing intercultural understanding. Proceedings of the 3rd international conference on intercultural collaboration, 49-58.

Garrido, C., \& Álvarez, I. (2006). Language teacher education for intercultural understanding. European Journal of Teacher Education, 29(2), 163-179.

Gökmen, E. (2005). Yabancı dil öğretiminde kültürlerarası iletişimsel edinç. Dil Dergisi 128, 69-77.

Hartman, A., and Ditfurth, M., (2007). Introduction to English Language Teaching. Stuttgart: Klett.

Ho, S. T. K. (2009). Addressing culture in EFL classrooms: The challenge of shifting from a traditional to an intercultural stance. Electronic journal of foreign language teaching, 6(1), 63-76.

Hoa, N. T. M. (2011). Developing EFL learners' intercultural communicative competence: A gap to be filled. Journal of English as an International Language: From Defining EIL Competence to Designing EIL Learning, 86-99.

Hofstede, G. (1994) Cultures and Organizations: Software of the Mind. London: HarperCollinsBusiness.

Irimia, M. L. (2012). Developing the intercultural dimension in language teaching. International Journal of Communication Research, 2(4), 325.

Jokikokko, K. (2005). Interculturally trained Finnish teachers' conceptions of diversity and intercultural competence. Intercultural Education, 16(1), 69-83.

Kazykhankyzy, L. (2019). The predictors of intercultural communicative competence in Turkish and Kazakh settings: academic self-concept and 12 motivational self-system. (Unpublished Doctoral Dissertation). Hacettepe University, Ankara.

Kramsch, C. J., McConnell-Ginet, S., \& Ginet-McConnell, S. (1992). Text and context: Cross- disciplinary perspectives on language study: DC Heath \& Co.

Kramsch, C., \& Widdowson, H. G. (1998). Language and culture. Oxford university press.

Lázár, I. (2005). Incorporating intercultural communicative competence in language teaching education. Council of Europe.

Lear, D. W., \& Abbott, A. R. (2008). Foreign language professional standards and CSL: Achieving the 5 C's. Michigan Journal of Community Service Learning, 14(2), 76-86. 
Lessard-Clouston, M. (1996). Chinese teachers' views of culture in their EFL learning and teaching. Language, Culture and Curriculum, 9(3), 197-224.

Liaw, M. 1. (2006). E-learning and the development of intercultural competence. Language Learning Technology, 10(3), 49-64.

López-Rocha, S. (2016). Intercultural communicative competence: creating awareness and promoting skills in the language classroom. Innovative language teaching and learning at university: enhancing participation and collaboration, 105.

Matsumoto, D. (1996) Culture and Psychology. Pacific Grove, CA: Brooks/Cole.

McKinnon, S. (2012). Global Perspectives. Internationalising the Curriculum at Glasgow Caledonian University, Project Plan.

Mirzaei, A., \& Forouzandeh, F. (2013). Relationship Between Intercultural Communicative Competence and L2-Learning Motivation of Iranian EFL Learners. Journal of Intercultural Communication Research, 42 (3), 300-318.

Moeller, A. J., \& Nugent, K. (2014). Building intercultural competence in the language classroom. In S. Dhonau (Ed.), 2014 report of the Central States Conference on the Teaching of Foreign Languages (pp. 1-18). Richmond, VA: Robert M. Terry.

Mostafaei Alaei, M., \& Nosrati, F. (2018). Research into EFL teachers' intercultural communicative competence and intercultural sensitivity. Journal of Intercultural Communication Research, 47(2), 73-86.

Omaggio, A.C. (1993). Teaching language in context. Boston: Heinle and Heinle.

Paige, R. M., Jorstad, H., Siaya, S., Klein, F., \& Colby, J. (2000). Culture learning in language education: A review of the literature. Unpublished manuscript, Center for Advanced Research on Language Acquisition, University of Minnesota.

Sercu, L. (2002). Implementing intercultural foreign language education. Belgian, Danish and British teachers' professional self-concepts and teaching practices compared. Evaluation $\mathcal{E}$ Research in Education, 16(3), 150-165.

Spencer-Oatey, H. (2012) What is culture? A compilation of quotations. GlobalPAD Core Concepts. Available at GlobalPAD Open House http://www.warwick.ac.uk/globalpadintercultural

Spitzberg, B. H. (1997). A model of intercultural communication competence. In L. A. Samovar $\quad \& \quad$ R. $\quad$ E. Porter (Eds.), Intercultural communication: A reader (pp. 379-391). Belmont, CA: Wadsworth

Thanasoulas, D. (2001). The importance of teaching culture in the foreign language classroom. Radical pedagogy, 3(3), 1-25.

Tran, T. Q., \& Seepho, S. (2016). EFL learners' attitudes toward intercultural communicative language teaching and their intercultural communicative competence development. Journal of Studies in the English Language, 11.

Vo, Q. P. (2017). Rethinking intercultural communication competence in English language teaching: a gap between lecturers' perspectives and practices in a southeast Asian tertiary context. i-manager's Journal on English Language Teaching, 7 (1), 20-29.

Wiseman, R. L. (2002). Intercultural communication competence. In W. B. Gudykunst \& B. Mody ～(Eds.), Handbook of international and intercultural communication (2nd ed.) (pp. 207- 224). Thousand Oaks, CA: Sage Publications.

Zhang, Y. (2017). A Study on ESL Teachers' Intercultural Communication Competence. English Language Teaching, 10(11), 229-235. 